\title{
Penggunaan Media Kartu Sampiran dan Isi (Kasamsi) untuk Meningkatkan Keterampilan Menulis Pantun dalam Subtema Memelihara Ekosistem Siswa Kelas V SD
}

\author{
RIZKA NUR OKTAVIANI \\ STKIP Bina Insan Mandiri Surabaya \\ E-mail : rizkanuroktavia@stkipbim.ac.id
}

\begin{abstract}
Abstrak :
Keterampilan menulis merupakan salah satu keterampilan penting dalam pelajaran Bahasa Indonesia. Pembelajaran bahasa Indonesia bahwa siswa kelas V harus mampu menulis pantun sesuai dengan ciri-ciri pantun. Berdasarkan hasil wawancara dan observasi, menunjukkan bahwa kemampuan siswa kelas V SDN Pegirian II/495 Surabaya dalam menulis pantun masih rendah. Hal itu terbukti dari hasil menulis pantun siswa belum dapat mencapai KKM yang telah ditetapkan, yaitu 70. Adapun penyebab permasalahan pembelajaran menulis pantun pada kelas $V$ di SDN Pegirian II/495 Surabaya, diantaranya yaitu tidak adanya media dalam pembelajaran tersebut, sehingga siswa kurang berminat dalam mengikuti kegiatan pembelajaran Bahasa Indonesia terutama dalam kegiatan menulis. Penelitian ini menggunakan rancangan penelitian tindakan kelas yang dilakukan dalam dua siklus dan setiap siklus memiliki tiga tahap yakni perencanaan, pelaksanaan dan observasi, serta refleksi. Hasil penelitian menunjukkan bahwa keterlaksanaan aktivitas guru selama pelaksanaan pembelajaran siklus I dan siklus II mendapatkan persentase keterlaksanaan 100\%. Sementara itu, skor ketercapaian aktivitas guru pada siklus I adalah 78,57 dan 89,46 pada siklus II. Adapun hasil belajar menulis pantun siswa pada siklus I memperoleh sebesar 76,64 dan 82,04 pada siklus II. Untuk ketuntasan klasikal hasil belajar siswa pada siklus I adalah 70.84 $\%$ dan siklus II diperoleh $86,73 \%$
\end{abstract}

Kata kunci: Media KASAMSI (Kartu Sampiran dan Isi), Menulis pantun

\section{Pendahuluan}

Pembelajaran Bahasa Indonesia mencakup empat keterampilan berbahasa yaitu keterampilan menyimak, berbicara, membaca, dan menulis. Keempat keterampilan tersebut mempunyai keterkaitan dan merupakan satu kesatuan yang tidak dapat dipisahkan antara satu dengan yang lain. Keterampilan menulis merupakan salah satu keterampilan penting dalam pembelajaran Bahasa Indonesia. Melalui keterampilan menulis, siswa dapat menuangkan ide, gagasan dan perasaannya dalam bentuk tulisan. Pengungkapan ide-ide tersebut dapat disampaikan 
melalui puisi, cerpen, pantun, maupun bentuk karangan lainnya.

Hasil observasi yang telah dilakukan pada siswa kelas $\mathrm{V}$ di SDN Pegirian II/495 Surabaya diperoleh fakta bahwa kemampuan siswa dalam menulis pantun di kelas $\mathrm{V}$ masih rendah dapat dilihat dari 34 siswa $66 \%$ belum dapat mencapai KKM yang telah ditetapkan, yaitu 70, sedangkan $34 \%$ lainnya telah berhasil mencapai KKM yang ditetapkan. Hal ini dapat ditunjukkan bahwa siswa belum mampu menuangkan ide-ide yang akan ditulis ke dalam bentuk tulisan, belum mampu menulis pantun sesuai dengan ciri-ciri pantun diantaranya beberapa siswa belum dapat membedakan sampiran dan isi, penyusunan suku kata 8-12, dan berrima a-b-a-b.

Selain itu, guru dalam pembelajaran belum menggunakan media pembelajaran. Dalam proses pembelajaran, guru hanya menjelaskan materi secara sekilas, kemudian memberikan tugas menulis pantun dengan batas waktu tertentu. Tidak adanya proses bimibingan dalam penyusunan sampiran dan isi. Setelah waktu pelajaran berakhir, guru meminta siswa mengumpulkan pantun yang sudah dibuat tanpa adanya membacakan di depan kelas. Proses pembelajaran yang seperti ini, menyebabkan miskonsepsi materi, kurang berhasil dalam pembelajaran menulis pantun dan tidak adanya komunikasi dua arah. Berdasarkan hasil observasi, disimpulkan bahwa penyebab permasalahan pembelajaran menulis pantun pada kelas V SDN Pegirian II/495 Surabaya, diantaranya yaitu tidak adanya media dalam pembelajaran tersebut, dalam proses pembelajaran hanya berpusat pada guru sehingga siswa tidak aktif, kurang berminat dalam mengikuti kegiatan pembelajaran Bahasa Indonesia terutama dalam kegiatan menulis pantun.

Untuk mengatasi permasalahan yang terjadi di kelas V di SDN Pegirian II/495 Surabaya, penulis berkolaborasi dengan guru kelas untuk memerbaiki dan meningkatkan kualitas pembelajaran menulis pantun. Adapun upaya yang dilakukan adalah dengan melakukan Penelitian Tindakan Kelas (PTK) dengan menggunakan media KASAMSI. Berdasarkan latar belakang di atas, maka penulis mengangkat judul "Penggunaan Media Kartu Sampiran dan Isi (KASAMSI) untuk Meningkatkan Keterampilan Menulis pantun dalam Subtema Memelihara Ekosistem Siswa Kelas V Sekolah Dasar".

Adapun rumusan masalah yang dipecahkan dalam penelitian ini antara lain: 1) Apakah penggunaan media KASAMSI dapat meningkatkan keterampilan menulis pantun siswa kelas V SDN Pegirian II/495 Surabaya?, 2) Bagaimanakah hasil belajar menulis pantun siswa kelas V SDN Pegirian II/495 Surabaya dengan menggunakan media KASAMSI?, 3) Apa sajakah kendala-kendala yang muncul dan bagaimanakah cara mengatasinya dalam pelaksanaan pembelajaran menulis pantun dengan menggunakan media KASAMSI siswa kelas V SDN Pegirian II/495 Surabaya?

Adapun tujuan dalam penelitian ini adalah untuk mendeskripsikan 
penggunaan media KASAMSI, hasil menulis pantun, dan cara mengatasi kendala-kendala yang muncul dalam pelaksanaan pembelajaran untuk meningkatkan keterampilan menulis pantun siswa kelas V SDN Pegirian II/495 Surabaya. Sementara itu, manfaat penelitiannya adalah bermanfaat bagi siswa untuk memudahkan dalam menulis pantun dengan menggunakan media KASAMSI, bermanfaat bagi guru untuk pertimbangan memilih media pembelajaran, membantu guru mengatasi kesulitan di kelas dengan media yang menyenangkan, sehingga pembelajaran tidak monoton.

Menurut Sadiman, dkk. (2010:6), kata media berasal dari bahasa Latin dan merupakan bentuk jamak dari kata medium yang secara harfiah berarti perantara atau pengantar. Kartu kata adalah kartu yang berbentuk lembaranlembaran persegi panjang atau bentuk yang lainnya (bentuk buah, binatang dan lain-lain) yang bertuliskan kata-kata yang mudah dicerna anak-anak (Jannah, 2012:8). Kartu kata dalam hal ini dimodifikasi menjadi kartu sampiran dan isi (KASAMSI). Dengan menggunakan KASAMSI kegiatan pembelajaran menulis pantun dapat dilakukan sambil bermain, karena dengan bermain siswa tidak terbebani dan menciptakan kebebasan berekspresi atau menuangkan ide dalam tugas menulis pantun. Dapat disimpulkan bahwa media KASAMSI merupakan perantara atau pengantar pesan berupa media kartu yang dapat dijadikan sebuah bahan dalam menulis pantun sesuai dengan ciri-ciri pantun.
Menulis adalah kegiatan sekaligus keterampilan yang terintegrasi, bahkan menulis selalu ada dalam setiap pembelajaran, sama halnya dengan membaca (Zainurrahman, 2011:186). Menulis dapat didefinisikan sebagai suatu kegiatan penyampaian pesan (komunikasi) dengan menggunakan bahasa tulis sebagai alat atau medianya (Suparno dan Yunus, 2010:3). Dalam menulis penggunaan bahasa tulis yang mudah dipahami orang lain sangat penting karena menulis merupakan alat komunikasi tidak langsung. Menulis sangat penting bagi pendidikan, karena memudahkan para pelajar dalam berpikir, merasakan dan menikmati hubungan-hubungan, memperdalam daya tanggap, memecahkan masalahmasalah yang dihadapi, menyusun urutan bagi pengalaman (Tarigan, 2008:22-23).

Pantun merupakan puisi asli Indonesia (Melayu). Pantun umumnya terbagi atas dua bagian yakni sampiran dan isi. Sampiran (dua larik pertama) merupakan pengantar isi pantun, yaitu pada kedua larik-larik berikutnya. Umumnya larik-larik dalam dua larik pertama (sampiran) hanya memilki hubungan persamaan bunyi dengan larik ketiga dan keempat dan tidak memiliki hubungan makna. Menurut Winarti, (2014:11) pantun memiliki ciri-ciri sebagai berikut: a) setiap bait terdiri atas empat larik (baris), b) banyaknya suku kata tiap larik sama atau hampir sama (biasanya terdiri 8-12 suku kata), c) bersajak a-b-a-b, dan d) larik pertama dan kedua disebut sampiran, sedangkan larik ketiga dan keempat disebut isi pantun (makna, 
tujuan dan tema pantun). Larik sampiran ini mengandung pengimbau bagi pendengar atau pembaca untuk segera mendengar atau membaca larik ketiga dan ke empat.

Menurut Winarti, (2014:11) jenis pantun terbagi berdasarkan isi, bentuk dan pemakaian, yang akan diuraikan sebagai berikut: a) menurut isinya, yaitu: (1) pantun bersuka cita, (2) berduka cita, (3) pantun jenaka, (4) pantun teka-teki, (5) pantun agama, (6) pantun nasihat, dan (7) pantun adat. b) menurut bentuknya, pantun dibedakan menjadi: (1) pantuk kilat, (2) biasa/empat seuntai, (3) pantun enam seuntai atau lebih, (4) pantun berkait, dan (5) pantun modern. Menurut pemakaiannya, pantun dibedakan menjadi: (1) pantun anak-anak, (2) pantun orang muda, dan (3) pantun orang tua. Dari berbagai jenis pantun tersebut, yang sesuai dengan materi subtema memelihara ekosistem adalah pantun nasehat dan pantun suka cita.

\section{Metode}

Rancangan penelitian ini, menggunakan rancangan penelitian tindakan kelas. Menurut Arikunto (2010:4), penelitian tindakan kelas adalah penelitian yang dilakukan oleh guru di dalam kelasnya sendiri melalui refleksi diri, dengan tujuan untuk memperbaiki kinerjanya sebagai guru, sehingga hasil belajar siswa menjadi meningkat. Oleh karena itu, dalam penelitian tindakan kelas dikenal adanya siklus yang terdiri atas beberapa tahap, yaitu: perencanaan, pelaksanaan, observasi, refleksi, dan revisi. Sementara itu, tujuan penelitian tindakan kelas ini adalah untuk meningkatkan keterampilan menulis pantun siswa kelas V SDN Pegirian II/495 Surabaya. Adapun upaya yang dilakukan adalah dengan menggunakan media KASAMSI dalam proses belajar mengajar.

Subjek penelitian ini adalah siswa dan guru kelas V SDN Pegirian II/495 Surabaya. Jumlah siswa yang menjadi subjek penelitian ada 27 siswa, yang terdiri dari 11 siswa laki-laki dan 16 siswa perempuan. Alasan menggunakan subjek di kelas V Surabaya adalah karena keterampilan menulis pantun siswa kelas $\mathrm{V}$ masih rendah yaitu $66 \%$ belum dapat mencapai KKM yang ditetapkan. Lokasi yang digunakan sebagai penelitian mengenai penggunaan media KASAMSI untuk meningkatkan kemampuan menulis pantun adalah SDN Pegirian II/495 yang terletak di Kelurahan Pegirian Kecamatan Semampir Kota Surabaya.

Penelitian tindakan kelas ini dilakukan guru kelas V SDN Pegirian II/495 Surabaya. Penelitian ini dilaksanakan dengan mengacu pada teori dan pandangan Kemmis dan Taggrat (dalam Trianto, 2011:30) yang menggunakan sistem spiral refleksi diri mulai dengan rencana (planning), tindakan (action), pengamatan (observing), dan refleksi (reflection). Hal tersebut dilakukan sebagai rangkaian kegiatan pada siklus pertama. Kemudian sesuai hasil refleksi siklus pertama, apabila ditemukan hal-hal yang belum baik akan dilakukan perbaikan tindakan 
pembelajaran pada siklus kedua. Penulis dengan guru kelas I menyusun rencana tindakan siklus kedua kemudian dilanjutkan dengan pelaksanaan tindakan siklus kedua, pengamatan atau observasi pada siklus kedua, dan diakhiri dengan refleksi siklus kedua, dilakukan rencana perbaikan tindakan pembelajaran pada siklus ketiga, pengamatan atau observasi dan diakhiri dengan refleksi, hal ini dilakukan secara berulang.

Data yang diperlukan dalam penelitian ini adalah data hasil observasi aktivitas guru, data hasil tes belajar, data hasil catatan lapangan, dan data hasil dokumentasi. Sementara itu Instrumen penelitian yang digunakan dalam penelitian ini berupa lembar observasi atau pengamatan aktivitas guru dan lembar tes hasil belajar menulis pantun siswa. Adapun deskripsi analisis 1, data hasil observasi didapat dari aktivitas guru saat proses pembelajaran berlangsung. Berdasarkan tabel instrumen penelitian aktivitas guru pertemuan I, dapat diketahui bahwa jumlah maksimal yang diperoleh dalam persentase keterlaksanaan adalah 14, karena total aktivitas yang akan dilakukan guru adalah 14. Sementara itu, berdasarkan tabel instrumen penelitian aktivitas guru pertemuan II, dapat diketahui bahwa jumlah maksimal yang diperoleh dalam persentase keterlaksanaan adalah 14, karena total aktivitas yang dilakukan guru adalah 14 . Data hasil pengamatan keterlaksanaan aktivitas guru saat proses pembelajaran berlangsung dianalisis dengan menggunakan rumus :
Persentase Keterlaksanaan $=\frac{f}{N} \times 100 \%$

Untuk mengetahui skor ketercapaian aktivitas guru ada 14 aktivitas guru yang perlu diamati dan skor ketercapaian tertinggi adalah 5 sedangkan skor ketercapaian minimum adalah 1. Maka, diperoleh rumus skor ketercapaian sebagai berikut:

Skor Ketercapaian $=\frac{\sum \text { skor ketercapaian }}{\sum \text { aktivitas guru }} \times 100$

Data hasil belajar didapat dari nilai siswa. Kemudian dianalisis dengan berpedoman pada pencapaian indikator keberhasilan yang telah ditetapkan sebelumnya. Perhitungan untuk mengetahui nilai akhir tiap-tiap siswa adalah digunakan rumus sebagai berikut:

$$
\text { Nilai Akhir }=\frac{\text { skor yang diperoleh }}{\text { skor maksimal }} \times
$$

Untuk mengetahui ketercapaian KKM menulis pantun, digunakan rumus ratarata kelas. KKM yang ditetapkan di SDN PEGIRIAN II/495 adalah 70. Perhitungan untuk nilai rata kelas adalah sebagai berikut:

$$
\mathrm{X}=\frac{\sum X}{\sum N}
$$

Indikator keberhasilan yang dipergunakan pada penelitian ini yaitu sebagai berikut: a) keterlaksanaan aktivitas guru dalam pembelajaran menulis pantun dengan penggunaan media KASAMSI memperoleh nilai keterlaksanaan $\quad \geq 80 \% \quad$ (Aqib, dkk., 2006:41), b) ketercapaian pelaksanaan pembelajaran $\geq 80$ (Aqib, dkk., 2006:41), c) pembelajaran dianggap tuntas apabila 
$>75 \%$ siswa mendapat nilai $\geq$ KKM yang ditetapkan, yaitu 70 (Djamarah dan Zain, 2006:107), d) kendala-kendala yang muncul dapat diatasi dengan baik, sehingga tujuan pembelajaran yang telah ditetapkan dapat tercapai.

\section{Hasil}

\section{Siklus 1}

Pada siklus I, hasil penelitian pelaksanaan pembelajaran menulis pantun dengan menggunakan media KASAMSI dipaparkan sesuai dengan tahapan-tahapan dalam penelitian tindakan kelas, yaitu sebagai berikut: a) tahap perencanaan, pada tahap ini ada 6 langkah diantaranya, langkah pertama melakukan persiapan untuk melaksanakan proses pembelajaran siklus I yaitu menganalisis kurikulum kelas I semester II, Kompetensi inti dan kompetensi dasar yang akan dijadikan dalam penelitian ini sesuai dengan standar kompetensi menulis adalah mengungkapkan pikiran, perasaan, dan informasi secara tertulis dalam bentuk cerita. Adapun kompetensi dasarnya adalah melantunkan dan menyajikan teks pantun dan syair tentang bencana alam serta kehidupan berbangsa dan bernegara secara mandiri dalam bahasa Indonesia lisan dan tulis dengan memilih dan memilah kosakata baku. Jadwal pelaksanaan siklus I di SDN Pegirian II/495 Surabaya, yaitu pertemuan pertama dilaksanakan pada hari selasa, 26 April 2016 dalam waktu 3 $\times 35$ menit dan pertemuan kedua dilaksanakan pada hari kamis, 12 Mei 2016 dalam waktu $3 \times 35$ menit.
Langkah yang ketiga adalah membuat RPP dengan menggunakan media KASAMSI, langkah keempat adalah membuat 2 macam KASAMSI. Setiap KASAMSI dalam penelitian ini kartu yang berisi beberapa sampiran dan beberapa isi dengan materi lingkungan hidup dan terjadinya bencana banjir. Media KASAMSI dalam penelitian siklus I ini terbuat dari kertas A4 glossy yang dilaminasi. Langkah kelima dan keenam adalah menyusun instrument penilaian. Tahap yang kedua adalah pelaksanaan tindakan dan observasi. Adapun pelaksanaan tindakan adalah pelaksanaan kegiatan pembelajaran dilaksanakan sesuai dengan rencana pelaksanaan pembelajaran yang telah dirancang yaitu pembelajaran menulis pantun dengan menggunakan media KASAMSI. Pelaksanaan pembelajaran meliputi: kegiatan awal, kegiatan inti, dan kegiatan akhir. Kegiatan awal yang dilakukan oleh guru adalah mengecek kesiapan belajar siswa dengan cara mengucapakan salam, menanyakan kabar siswa, mengecek kelas dan mengabsensi siswa. Kegiatan ini dilaksanakan oleh guru dengan sangat baik.

Setelah itu, guru melakukan apersepsi yang mencakup menyampaikan topik pembelajaran dan bertanya jawab dengan siswa tentang menulis pantun dan akibat terjadi bencana alam. Kegiatan apersepsi dilakukan guru dengan baik, karena dalam menyampaikan topik pembelajaran guru menggunakan suara keras, jelas, dan sesuai dengan topik pembelajaran walaupun kurang bersemangat. Suasana 
di kelas menjadi ramai karena masingmasing siswa menyebutkan akibat terjadi bencana alam tidak dikondisikan. Kegiatan ini, dilakukan guru baik, karena ketika bertanya jawab semua siswa tampak antusias menjawab namun, suasana kelas menjadi tidak kondusif dan menjadi gaduh.

Setelah itu, guru menyampaikan tujuan pembelajaran. Dalam menyampaikan tujuan pembelajaran, guru melaksanakannya dengan sangat baik, karena guru menuliskan tujuan pembelajaran dipapan tulis dengan jelas, runtut, dan mengilustrasikan materi. Pada kegiatan inti kegiatan yang dilakuan guru adalah menunjukkan media KASAMSI. Kegiatan ini dilaksanakan oleh guru dengan baik karena dalam menunjukkan media KASAMSI dengan memberikan intruksi menggunakan media kasamsi, namun suara guru tidak dapat terdengar pada siswa yang dibelakang.

Guru menjelaskan materi pembelajaran tentang menulis pantun. Kegiatan dalam menjelaskan materi ini, dilaksanakan oleh guru sudah baik, karena dalam menjelaskan materi cerita guru sudah runtut dan jelas, tetapi volume guru dalam menjelaskan belum dapat didengar oleh seluruh isi kelas. Guru mendemonstrasikan cara menentukan sampiran dan isi dalam menulis pantum. Kemudian dilanjutkan dengan mendemonstrasikan cara menyusun pantun sesuai dengan kartu sampiran dan isi yang masing-masing diperoleh setiap siswa. Kegiatan ini dilaksanakan oleh guru dengan cukup baik, karena guru sudah memberikan contoh cara menyusun kerangka cerita, namun masih membingungkan siswa.

Selanjutnya guru memberi tugas siswa untuk menyusun sampiran atau isi pantun berdasarkan KASAMSI yang sudah diperoleh siswa yang terdapat dalam LKS. Kegiatan ini dilakukan guru dengan baik. Guru membimbing siswa dalam mengerjakan LKS. Kegiatan ini dilakukan guru dengan cukup baik, karena hanya beberapa siswa saja yang dibimbing oleh guru. Siswa diminta oleh guru untuk membacakan hasil susunan menulis pantun di depan kelas. Kegiatan ini dilaksanakan oleh guru dengan sangat baik karena siswa sangat bersemangat ketika guru meminta siswa untuk membacakannya di depan kelas. Guru memberikan umpan balik dengan memberikan penguatan terhadap hasil kerja siswa apabila terdapat kesalahan atau kekurangan. Kegiatan ini dilakukan oleh guru dengan cukup baik, karena guru hanya beberapa siswa yang diberi masukan terhadap hasil menulis pantun yang dibuat oleh siswa.

Pada kegiatan akhir, guru memberikan lembar penilaian individu dan kartu sampiran/isi untuk menulis isi/sampiran pada pantun dengan materi terjadinya banjir, setelah itu guru menyimpulkan materi pembelajaran. Dalam kegiatan ini, kegiatan ini dilaksanakan oleh guru dengan cukup baik, karena dalam menyimpulkan materi guru belum melibatkan siswa, sehingga siswa cenderung pasif. Guru memberikan tugas rumah untuk menulis pantun sesuai dengan ciri-ciri pantun, selanjutnya guru menutup pelajaran dengan menyampaikan pesan moral 
kepada siswa. Pada tahap observasi kegiatan yang dilakukan adalah pada siklus I terhadap aktivitas guru dalam proses pembelajaran diamati oleh guru sebagai observer dan guru pendamping kelas pengamat yaitu Bapak Mufa'id S.Pd, selaku guru kelas V SDN Pegirian II/495 Surabaya. Kegiatan pengamatan dilakukan bersamaan dengan proses pembelajaran.

Berdasarkan data aktivitas guru selama pelaksanaan pembelajaran pertemuan pertama mendapatkan persentase keterlaksanaan $100 \%$ dengan ketercapaian sebesar 78,57. Perolehan ketercapaian tersebut jika dikriteriakan terhadap aktivitas guru dalam melaksanakan pembelajaran, maka aktivitas guru dalam melaksanakan pembelajaran pada siklus I pertemuan pertama dikriteriakan baik. Kegiatan pembelajaran yang mendapat nilai ratarata 5 yaitu saat guru mempersiapkan kesiapan belajar siswa dalam pembelajaran dan pada saat meminta siswa untuk membacakan atau mempresentasikan hasil kerangka cerita yang telah dibuat siswa di depan kelas. Untuk rata-rata 4 yaitu saat guru melakukan apersepsi, menyampaikan tujuan pembelajaran, menujukkan media KASAMSI, mendemonstrasikan cara menulis pantun dengan media KASAMSI, meminta siswa untuk latihan menyusun kerangka cerita, memberikan tugas rumah untuk menulis pantun sesuai dengan ciri-ciri pantun dan kegitan guru menutup pelajaran.

Kegiatan pembelajaran yang mendapat nilai rata-rata 3 yaitu saat guru menjelaskan materi pembelajaran tentang menulis pantun, mendemonstrasikan cara menulis pantun sesuia petunjuk menggunakan media KASAMSI, membimbing siswa dalam menyusun sampiran dan isi, menyimpulkan materi pembelajaran. Untuk rata-rata 2 yaitu saat guru memberikan umpan balik dengan memberikan penguatan terhadap hasil kerja siswa bila terdapat kesalahan atau kekurangan. Hal ini menunjukkan proses pembelajaran berjalan dengan baik tetapi masih perlu diperbaiki lagi untuk siklus berikutnya karena masih ada aspek-aspek yang lain yang belum terlaksana dengan baik seperti yang telah direncanakan.

Hasil nilai rata- rata tes hasil belajar siswa menulis pantun dengan menggunakan media KASAMSI siklus I sebesar 76,64, dengan siswa yang mendapat nilai $\geq 70$ sebanyak 18 siswa dan persentase ketuntasan hasil belajar siswa sebesar 74,84\%. Persentase tersebut jika dikualifikasikan pada ketuntasan hasil belajar siswa, maka ketuntasan hasil belajar siswa sudah baik, namun belum mencapai target peneliti yaitu ketuntasan hasil belajar $\geq 76 \%$ maka penelitian ini dikategorikan belum berhasil. Oleh karena itu, perlu adanya perbaikan tindakan yang akan dilaksanakan pada siklus II. Setelah kegiatan pembelajaran dilaksanakan, peneliti dan guru kelas merefleksi kegiatan yang telah dilaksanakan. Secara keseluruhan guru sudah melaksanakan kegiatan pembelajaran dengan baik, tetapi ada beberapa kegiatan yang belum maksimal dan perlu diperbaiki. 
Saat guru menjelaskan materi pembelajaran tentang menulis pantun, masih ada beberapa siswa yang ramai sehingga mengganggu siswa yang lain. Jadi, untuk pertemuan selanjutnya sebaiknya guru mengondisikan siswa terlebih dahulu sebelum menjelaskan materi pembelajaran. Pada saat guru mendemonstrasikan cara menyusun sampiran dan isi sesuai dengan media KASAMSI yang sudah diperoleh siswa, suara guru kurang keras dan menulis pantun sesuai dengan ciri-ciri pantun yang ditulis oleh guru di papan tulis terlalu kecil, sehingga siswa yang duduknya dibelakang dapat melihat dengan jelas. Oleh karena itu, pada pertemuan selanjutnya suara guru harus lebih keras sehingga dapat didengar suluruh siswa dalam kelas. Dalam menuliskan pantun di papan tulis, guru harus lebih jelas lagi sehingga tulisan tetap bisa terbaca oleh siswa yang duduk di bangku belakang.

Guru membimbing siswa dalam menyusun kerangka cerita, sudah baik, karena guru sudah mendatangi siswa, guru melihat kondisi siswa pada saat mengerjakan, namun tidak menunjuk kesalahan tulisan siswa ataupun mencari alternatif pemecahan masalah yang dihadapi siswa. Sebaiknya pada pertemuan selanjutnya guru membimbing siswa menulis pantun, dengan menunjuk kesalahan tulisan siswa, dan mencari alternatif pemecahan masalah yang dihadapi siswa. Pada saat guru memberikan umpan balik pada siswa guru hanya memberikan beberapa pertanyaan saja, guru tidak mengembangkan pertanyaan siswa.
Pada

pertemuan

selanjutnya sebaiknya guru dapat mengembangkan pertanyaan umpan balik yang sampaikan kepada siswa. Pada saat kegiatan menyimpulkan materi pembelajaran, guru tidak mengajak siswa dalam menyimpulkan materi pembelajaran. Sehingga, pada pertemuan selanjutnya sebaiknya guru mengajak siswa untuk menyimpulkan materi pembelajaran. Pada pelaksanaan pembelajaran menulis pantun dengan menggunakan media KASAMSI ini juga mengalami kendalakendala yang terangkum dalam hasil catatan lapangan. Kendala-kendala yang dihadapi adalah guru masih sulit mengontrol siswa dengan adanya bimbingan dari kesalahan penulisan, suara guru kurang keras, sehingga siswa yang tempat duduknya di belakang tidak bisa mendengarkan penjelasan guru dengan jelas serta guru kurang bisa mengelola waktu dengan baik. Adapun cara untuk mengatasi kendala-kendala di atas yaitu guru mengondisikan siswa dengan melakukan ice breaking berupa tepuk diam. Suara guru harus lebih keras agar siswa yang tempat duduknya di belakang dapat mendengarkan penjelasan guru dengan jelas, lebih mengatur waktu, memberi batasan waktu saat siswa mengerjakan, agar siswa tidak ramai dan guru dapat mengatur waktu sesuai dengan RPP.

\section{Siklus II}

Pada siklus II, hasil penelitian pelaksanaan pembelajaran menulis pantun dengan menggunakan media KASAMSI dipaparkan sesuai dengan tahapan-tahapan dalam penelitian 
tindakan kelas, yaitu sebagai berikut: tahap perencanaan, tahap ini terdapat 6 langkah langkah yang pertama adalah peneliti melakukan persiapan untuk melaksanakan proses pembelajaran pada siklus II, yaitu sebagai berikut, menentukan jadwal penelitian dengan pihak sekolah. Jadwal pelaksanaan siklus II di kelas V SDN Pegirian II/495 Surabaya, yaitu pertemuan pertama dilaksanakan pada hari Kamis, 26 April 2016 dalam waktu $3 \times 35$ menit, langkah yang keduan yaitu membuat rencana pelaksanaan pembelajaran menulis pantun dengan menggunakan media KASAMSI, langkah ketiga adalah membuat media KASAMSI. KASAMSI yang pertama dalam penelitian ini terdiri atas 5 kartu sampiran dan 4 kartu isi dengan materi manfaat menjaga kesehatan tubuh Media KASAMSI dalam penelitian siklus II ini terbuat dari kertas A4 kertas glossy yang dilaminasi. Untuk langkah selanjutnya adalah menyusun instrument penelitian.

Pelaksanaan tindakan dan observasi. Adapun pelaksanan tindakan kegiatan pembelajaran dilaksanakan sesuai dengan rencana pelaksanaan pembelajaran yang telah dirancang yaitu pembelajaran menulis pantun dengan menggunakan media KASAMSI. Pelaksanaan pembelajaran meliputi: kegiatan awal, kegiatan inti, dan kegiatan akhir. Kegiatan awal yang dilakukan oleh guru adalah mengecek kesiapan belajar siswa dengan cara mengucapakan salam, menanyakan kabar siswa, mengecek kelas dan mengabsensi siswa. Kegiatan ini dilaksanakan oleh guru dengan sangat baik. Guru melakukan apersepsi yang mencakup menyampaikan topik pembelajaran dan bertanya jawab dengan siswa tentang menulis pantun. Kegiatan apersepsi dilakukan guru dengan sangat baik, karena dalam menyampaikan topik pembelajaran guru sangat bersemangat, menggunakan suara keras, jelas, dan sesuai dengan topik pembelajaran.

Setelah itu, guru menyampaikan tujuan pembelajaran. Dalam menyampaikan tujuan pembelajaran, guru melaksanakannya dengan sangat baik, karena guru menuliskan tujuan pembelajaran dipapan tulis dengan jelas, runtut, dan dapat mengilustrasikan materi pembelajaran. Pada kegiaan inti guru menunjukkan media KASAMSI. Kegiatan ini dilaksanakan oleh guru dengan sangat baik, karena guru dapat mengondisikan siswa. Kegiatan menjelaskan materi pelajaran dilaksanakan oleh guru dengan sangat baik, karena dalam menjelaskan materi cerita guru sudah runtut dan jelas, dan volume guru dalam menjelaskan pun dapat didengar oleh seluruh isi kelas. Guru mendemonstrasikan cara menuliskan sampiran/isi pada pantun sesuai dengan KASAMSI yang diperoleh masing-masing siswa kegiatan ini dilaksanakan oleh guru dengan baik, karena guru dalam mendemontrasikan suaranya jelas, sehingga siswa dapat dengan jelas bagaimana cara menulis pantun. Selanjutnya guru memberi tugas siswa untuk menulis pantun sesuai dengan KASAMSI yang terdapat dalam LKS. Kegiatan ini dilakukan guru dengan baik. Guru membimbing siswa dalam mengerjakan LKS. Kegiatan ini dilakukan 
guru dengan baik, karena guru sudah membimbing hampir dari keseluruhan siswa.

Siswa diminta oleh guru untuk membacakan hasil menulis pantun di depan kelas. Kegiatan ini dilaksanakan oleh guru dengan sangat baik karena siswa sangat bersemangat ketika guru meminta siswa untuk membacakannya di depan kelas. Guru memberikan umpan balik dengan memberikan penguatan terhadap hasil kerja siswa apabila terdapat kesalahan atau kekurangan. Kegiatan ini dilakukan oleh guru dengan baik, karena guru membahas hasil kerja siswa, dengan melihat dan memberikan pembetulan terhadap menulis pantun yang telah dibuat oleh siswa sesuai dengan ciri-ciri pantun. Pada kegiatan akhir, guru menyimpulkan materi pembelajaran. Dalam kegiatan ini, kegiatan ini dilaksanakan oleh guru dengan baik, karena dalam menyimpulkan materi guru melibatkan siswa, sehingga siswa menjadi aktif. Guru memberikan tugas rumah untuk menulis pantun dengan materi akibat banjir, selanjutnya guru menutup pelajaran dengan menyampaikan pesan moral kepada siswa.

Kegiatan observasi pada siklus II terhadap aktivitas guru dalam proses pembelajaran diamati oleh dua observer yaitu Bapak Mufaid, S.Pd selaku guru kelas V SDN Pegirian II/495Surabaya. Kegiatan pengamatan dilakukan bersamaan selama proses pembelajaran. Data aktivitas guru selama pelaksanaan pembelajaran pertemuan pertama mendapatkan persentase keterlaksanaan $100 \%$ dengan ketercapaian sebesar 89,46.
Perolehan ketercapaian tersebut jika dikriteriakan terhadap aktivitas guru dalam melaksanakan pembelajaran, maka aktivitas guru dalam melaksanakan pembelajaran pada siklus II pertemuan pertama dikriteriakan sangat tinggi.

Sementara itu hasil nilai rata- rata tes hasil belajar siswa menulis pantun dengan menggunakan media KASAMSI siklus II sebesar 82,04 dengan siswa yang mendapat nilai $\geq 70$ sebanyak 24 siswa dan persentase ketuntasan hasil belajar siswa sebesar $86.73 \%$. Tahap refleski yaitu Setelah kegiatan pembelajaran dilaksanakan, peneliti dan guru kelas merefleksi kegiatan yang telah dilaksanakan. Secara keseluruhan guru sudah melaksanakan kegiatan pembelajaran dengan baik, tetapi ada beberapa kegiatan yang belum maksimal dan perlu diperbaiki.

Pada saat guru mendemonstrasikan cara menentukan dan menulis pantun sesuai dengan media KASAMSI, pantun yang ditulis oleh guru di papan tulis sudah jelas, walaupun suara guru belum jelas dalam memberikan penjelasan kerangka karangan yang telah ditulis oleh siswa. Oleh karena itu, pada pertemuan selanjutnya suara guru harus lebih keras sehingga dapat didengar suluruh siswa dalam kelas. Guru membimbing siswa dalam menyusun pantun sesuai dengan ciri-ciri pantun sudah baik, karena selain mendatangi siswa, guru juga melihat kondisi siswa pada saat mengerjakan, menunjuk kesalahan tulisan siswa serta mencari alternatif pemecahan masalah yang dihadapi siswa walaupun tidak semua siswa yang dibimbing oleh guru. Oleh 
karena itu, pada pertemuan selanjutnya guru membimbing siswa menulis pantun harus lebih merata lagi, sehingga semua siswa merasakan bimbingan dari guru.

Pada saat kegiatan menyimpulkan materi pembelajaran, guru mengajak siswa dalam menyimpulkan materi pembelajaran dilanjutkan dengan pemberian tugas rumah. Dalam menutup pembelajaran, guru tidak membacakan agenda pertemuan selanjutnya. oleh karena itu, diharapkan guru membacakan agenda untuk pertemuan selanjutnya. Pada pelaksanaan pembelajaran menulis pantun dengan menggunakan media KASAMSI ini juga mengalami kendala-kendala yang terangkum dalam hasil catatan lapangan. Kendala-kendala yang dihadapi adalah guru kurang bisa dalam menggunakan pilihan kata yang tepat saat menyusun sampiran maupun isi, megelola waktu yang sudah ditulis dalam rencana pelaksanaan pembelajaran, guru masih sulit mengontrol siswa, suara guru kurang keras, sehingga siswa yang tempat duduknya di belakang membutuhkan penjelasan ulang dari guru.

Adapun cara untuk mengatasi kendala-kendala di atas yaitu guru harus pandai memilih kata dalam mengembangkan kerangka cerita serta harus senantiasa melihat jam berapa waktu yang diperlukan dalam melakukan kegiatan awal, inti dan akhir, sehingga pembelajaran akan berakhir tepat pada waktu yang direncakan pada RPP. Guru mengondisikan siswa dengan melakukan ice breaking berupa tepuk pintar, mengatur tempat duduk siswa, Suara guru harus lebih keras agar siswa yang tempat duduknya di belakang dapat mendengarkan penjelasan guru dengan jelas, lebih mengatur waktu, memberi batasan waktu saat siswa mengerjakan, agar siswa tidak ramai dan guru dapat mengatur waktu sesuai dengan RPP.

Hasil dari penelitian penggunaan media KASAMSI untuk meningkatkan keterampilan menulis pantun pada siswa kelas V SDN Pegirian II/495 Surabaya mencapai hasil yang maksimal. Secara keseluruhan siswa mengikuti pembelajaran dengan baik selama pelaksanaan siklus I dan siklus II. Pada pelaksanaan pembelajaran menulis pantun dengan menggunakan media KASAMSI dalam siklus I belum mencapai kriteria yang diharapkan. Hal tersebut terlihat dari hasil observasi aktivitas guru pada pertemuan pertama memperoleh skor ketercapaian sebesar 78.57. Hal ini disebabkan guru belum mampu mengondisikan siswa dalam proses pembelajaran dan suara guru kurang keras, sehingga kelas menjadi ramai.

Setelah ada perbaikan kegiatan pembelajaran pada siklus II, maka terlihat adanya peningkatan yang terjadi pada siklus II pertemuan pertama memperoleh skor ketercapaian sebesar 89,64. Skor ketercapaian pada siklus II ini sudah mencapai kriteria keberhasilan dalam pembelajaran yaitu $\geq 80$ dari seluruh aktivitas guru. Perolehan skor tersebut jika dikriteriakan pada skor ketercapaian aktivitas guru, maka ketercapaian tersebut sangat tinggi. Hal tersebut sesuai dengan pendapat Aqib, Zainal dkk, 
menyatakan bahwa tingkat ketercapaian aktivitas guru dikatakan berhasil atau sangat tinggi apabila mendapat persentase $>80 \%$.

Adapun kendala-kendala yang muncul pada proses pembelajaran menulis pantun dengan menggunakan media KASAMSI, yaitu guru masih sulit mengontrol siswa dan suara guru kurang keras. Untuk mengatasi kendala-kendala di atas, guru harus menggunakan media KASAMSI dalam pembelajaran menulis pantun, sehingga siswa dapat lebih mudah untuk menulis pantun sesuai dengan ciri-ciri pantun, meningkatkan volume suara guru untuk lebih keras,

Hasil belajar siswa pada siklus I yaitu ketuntasan klasikal yang diperoleh siswa mencapai 74,84\%. Skor ketuntasan tersebut belum mencapai kriteria ketuntasan secara klasikal yang diharapkan. Pada siklus II hasil belajar siswa mengalami peningkatan yaitu $86,73 \%$. Skor ketuntasan pada siklus II mencapai kriteria ketuntasan secara klasikal $\geq 76 \%$ dan jika dikriteriakan pada ketuntasan hasil belajar siswa, maka ketuntasan hasil belajar siswa sudah baik sekali. Hal tersebut sesuai dengan pendapat Djamarah dan Zain (2006:121), menyatakan bahwa tingkat keberhasilan proses belajar mengajar dikatakan berhasil atau baik sekali apabila mendapat persentase $76 \%-99 \%$.

Dilihat dari semua hasil yang telah diperoleh pada proses pembelajaran menulis narasi dengan menggunakan media KASAMSI dari siklus I dan siklus II, maka penggunaan media KASAMSI dapat meningkatkan keterampilan menulis pantun yang telah dilaksanakan oleh peneliti pada kelas V SDN Pegirian II/495 Surabaya. Hal ini didukung oleh pendapat Jannah (2012:8) menjelaskan kartu kata adalah kartu yang berbentuk lembaran-lembaran persegi panjang atau bentuk yang lainnya (bentuk buah, binatang dan lain-lain) yang bertuliskan kata-kata yang mudah dicerna anakanak. Dapat disimpulkan bahwa media KASAMSI merupakan perantara atau pengantar pesan berupa media kartu yang dapat dijadikan sebuah bahan dalam menulis pantun sesuai dengan ciriciri pantun.

\section{Kesimpulan}

Dari hasil penelitian yang dilakukan selama 2 siklus, menunjukkan bahwa penggunaan media KASAMSI untuk meningkatkan keterampilan menulis pantun siswa kelas V SDN Pegirian II/495 Surabaya menunjukkan peningkatan. Penigkatan tersebut dapat dilihat pada aktivitas guru, hasil belajar siswa, dan kendala-kendala yang dapat diatasi dengan baik. Pada pelaksanaan pembelajaran menulis pantun dengan menggunakan media KASAMSI, mulai dari dan sampai pada kegiatan akhir. Berdasarkan hasil observasi yang dilakukan oleh dua observer, menunjukkan bahwa terjadi peningkatan aktivitas guru selama pembelajaran dengan menggunakan media KASAMSI. Hal ini terbukti pada siklus I aktivitas guru memperoleh skor ketercapaian 78,57 dan 89,64 pada siklus II.

Hasil belajar siswa pada pembelajaran menulis pantun dengan menggunakan media KASAMSI pada 
siklus I mencapai $76,64 \%$ dan $82.04 \%$ pada siklus II. Hal ini menunjukkan bahwa adanya peningkatan hasil belajar siswa dari siklus I ke siklus II. Kendalakendala yang muncul pada proses pembelajaran menulis pantun dengan menggunakan media KASAMSI, yaitu guru belum bisa menguasai kelas, suara guru kurang keras, , guru kurang bisa mengelola waktu pembelajaran. Dari kendala-kendala di atas, maka peneliti mampu mengatasi dengan cara guru bisa menguasai kelas dengan baik, dengan memberikan ice breaking berupa tepuk diam pada siswa. Meningkatkan suara guru untuk lebih jelas dan keras, sehingga siswa mengerti isi dari penjelasan guru. Memberikan contoh cara menyusun dan mengembangkan kerangka cerita dengan menngunakan pilihan kata yang tepat yang sesuai dengan ciri-ciri pantun. Memperhitungkan waktu setiap kegiatan pembelajaran yang dilakukan, sehingga pembelajaran dapat selesai sesuai dengan waktu yang telah direncanakan pada rencana pelaksanaan pembelajaran.

Berdasarkan kesimpulan di atas, maka peneliti menyarankan agar guru menggunakan media KASAMSI pada pembelajaran menulis pantun. Media pembelajaran KASAMSI ini, memudahkan siswa dalam membuat pantun, sehingga siswa dapat menulis pantun sesuai dengan ciri-ciri pantun dengan benar. Disarankan guru dalam menggunakan media KASAMSI, dengan memerhatikan font dan ukuran tulisannya sehingga dapat terlihat oleh semua siswa.

\section{Daftar Pustaka}

Arikunto, Suharsimi, dkk. (2011). Penelitian Tindakan Kelas. Jakarta: PT. Bumi Aksara.

Aqib, Zainal. (2006). Penelitian Tindakan Kelas untuk Guru. Bandung:Yrama Widya

Arikunto, Suharsimi. (2006). Prosedur Penelitian Suatu Pendekatan Praktik. Jakarta: Rineka Cipta

Jannah, Lilik Nur. (2014). Penggunaan Media Kartu Kata Untuk Meningkatkan Kemampuan Membaca Permulaan Pada Anak Tk Al-Aziez Kelompok B Pabean Cantian Surabaya (skripsi) Surabaya: Universitas Negeri Surabaya

Sadiman, Arief, dkk.(2007). Media Pendidikan. Jakarta: Raja Grafindo.

Sudjana dan Ahmad Rivai. (2010.) Media Pengajaran. Bandung: Sinar Baru Algensindo.

Sukino. (2010). Menulis itu Mudah. Yogyakarta: Pustaka Populer.

Suparno dan Mohamad Yunus. (2010). Keterampilan Dasar Menulis. Jakarta: Universitas Terbuka.

Tarigan, Djago. (2008). Membina Keterampilan Menulis Paragraf. Bandung: Angkasa

Zainurrahman. 2011. Menulis dari Teori Hingga Praktik. Bandung: Alfabet. 

